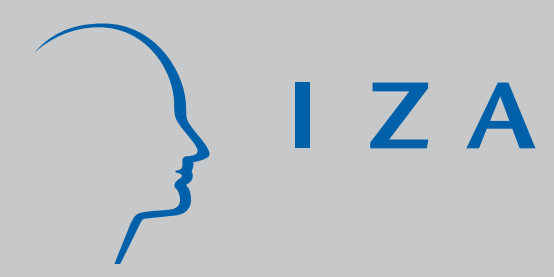

IZA DP No. 1357

Intermittent Employment: Work Histories of Israeli Men and Women, 1983-1995

Shoshana Neuman

Adrian Ziderman

October 2004 


\title{
Intermittent Employment: Work Histories of Israeli Men and Women, 1983-1995
}

\author{
Shoshana Neuman \\ Bar-Ilan University, \\ CEPR and IZA Bonn
}

Adrian Ziderman

Bar-Ilan University

\section{Discussion Paper No. 1357 \\ October 2004}

\author{
IZA \\ P.O. Box 7240 \\ 53072 Bonn \\ Germany \\ Phone: +49-228-3894-0 \\ Fax: +49-228-3894-180 \\ Email: iza@iza.org
}

\begin{abstract}
Any opinions expressed here are those of the author(s) and not those of the institute. Research disseminated by IZA may include views on policy, but the institute itself takes no institutional policy positions.

The Institute for the Study of Labor (IZA) in Bonn is a local and virtual international research center and a place of communication between science, politics and business. IZA is an independent nonprofit company supported by Deutsche Post World Net. The center is associated with the University of Bonn and offers a stimulating research environment through its research networks, research support, and visitors and doctoral programs. IZA engages in (i) original and internationally competitive research in all fields of labor economics, (ii) development of policy concepts, and (iii) dissemination of research results and concepts to the interested public.
\end{abstract}

IZA Discussion Papers often represent preliminary work and are circulated to encourage discussion. Citation of such a paper should account for its provisional character. A revised version may be available directly from the author. 


\section{ABSTRACT \\ Intermittent Employment: Work Histories of Israeli Men and Women, 1983-1995*}

This study examines the extent, duration and timing of employment breaks amongst a large representative sample of Jewish workers in Israel over the 13-year time period, 1983-1995. Work histories are constructed from a new joint database, unique in Israel, which was derived from a linkage of 1995 Population Census data with monthly employment records of the National Insurance Institute. The paper focuses on gender differences in work history patterns and, within each gender, breakdowns are provided by ethnic origin, marital status, age and education level.

While most of the results are both expected and compatible with current economic theories of household behavior, some of the findings of the study are less expected, particularly those relating to the considerable amount of intermittent employment found amongst Israeli male workers. Also, women's labor market attachment is stronger than is generally presumed. Gender differences in employment interruptions are greater for younger than older workers.

JEL Classification: J12, J15, J16, J21, J22

Keywords: $\quad$ spells, non-employment, gender, ethnicity, age education, marital status, Israel

Corresponding author:

Shoshana Neuman

Department of Economics

Bar-llan University

52900 Ramat-Gan

Israel

Email:neumans@mail.biu.ac.il

\footnotetext{
* The research was supported by a grant from the Pinhas Sapir Center for Development, Tel Aviv University; an early version of the paper appeared in the Center's Discussion Paper Series (Neuman and Ziderman, 2003). Tammy Shterental provided high quality technical research assistance.
} 


\section{Introduction}

Over recent decades our understanding of many facets of the working of labor markets has been enhanced considerably by the growth of an extensive empirical literature based on large-scale longitudinal labour market data sets. The availability of extensive data on individual work histories (in turn facilitating measures of the extent and timing of employment breaks and of accumulated labour market experience) has spawned research that has led to a reevaluation of the conventional wisdom in many central areas of labor market research, including the effect of accumulated labour market experience of wages, the efficacy (and depreciation) of human capital investments and, given the greater incidence of intermittent labor force participation amongst women, gender issues.

But this literature, based on such extensive data sets as the National Longitudinal Survey Labor Market Experience (NLS) and the Panel Study of Income Dynamics (PSID), has been largely confined to the United States labour market, though there are some studies drawn from European countries.

In Israel, as in most other countries, longitudinal labour force data are generally lacking ${ }^{1}$. Most empirical labor market research in Israel has been based on crosssectional data sets such as the Census of Population, the Labor Force Survey and the Survey on Labor Force Mobility. No information on individual work histories is provided in these surveys. This paper, and the broader research program of which it forms part, aims at making some contribution towards filling this information gap.

The research reported in this paper is based on the construction of a new, combined database, which provides information on individual labor market histories, over a thirteen-year period. Individual background information on the 20 percent sample in the 1995 Population Census is matched with data on individual work histories (including employment breaks) from National Insurance Institute records. The method of the micro linkage of national insurance data to other data sources is not new in Israel and has been used fruitfully in the past. Indeed, one of the authors, extending a pioneering study by Borus (1977), matched national insurance wages and work history data over a seven year period with background information on a sample of graduates from alternative training courses. This linked data set was used to study the effectiveness of alternative training modes for youth in Israel (Ziderman, 1989). But the study related to a sample of only 1200 individuals. What is new in the micro data linking reported in this paper is the size and scope of the new database, covering some 20 percent of the population under scrutiny.

This combined database is used, in this paper, to describe patterns of intermittent employment histories in Israel, over the 13-year period 1983-1995. The descriptive statistical analysis examines differences in work pattern histories for groups of workers, defined by gender, ethnic background, marital status, age group and education. Regression analysis is then used to estimate the net effects of these socioeconomic variables and their significance. 


\section{Constructing the Data Base}

As in most other countries a single-data source providing individual labor market histories, together with other socio-economic information, is unavailable in Israel, particularly for a large representative sample of the population. A unique opportunity to construct such a database was provided by the "1995 Census Research and Analysis Program" of the Central Bureau of Statistics. Under this program the Bureau undertook, for the authors, the complicated task of linking two large micro data sets individual work histories from the National Insurance Institute (NII) database, with socio-economic data relating to a 20 percent sample of individuals drawn from the 1995 Population Census.

The NII receives information on individuals' employment start and finish dates for each period of continuous work. A work break was defined as non-work for at least one month. On the basis of this information, the timing and length of all periods of work and of work breaks was computed, month by month, for all individuals in the sample, both for those at present employed and for those experiencing a work break. For each individual in the sample, a vector of the timing and length of work periods and work breaks was recorded. Because of weaknesses in the NII data base for earlier years, these monthly work histories could be constructed only for a 13-year period prior to the Census year: thus work histories covered the period 1983-1995. Work histories were linked to data on personal characteristics for a sample of individuals from the 1995 Census.

The Census of Population is the most comprehensive source of demographic and socio-economic data on the Israeli population. The extended questionnaire, filled out by 20 percent of the population, provides information, for all individuals aged $15+$, on such items as marital status, labor force characteristics, schooling, ethnic background and income. Data from the 20 percent sample were matched with individual work profiles and earnings data from the NII; successful matching of NII and Census data was achieved for some 544,000 individuals; this new joint data source constitutes a unique longitudinal data set on the work histories of a large representative sample of the Israeli population of working age.

The sub-sample drawn for the present study consists of 215,133 individuals, 104,240 men and 110,893 women; of these, 69.8 percent of men and 62.9 percent of women were currently working (December 1995). The rest were either unemployed or out of the labor force; neither Census data nor NII records distinguish between these types of non-work ${ }^{2}$. The sub-sample was restricted to Jewish individuals between the ages of 35 and 59. The lower age limit was chosen in order to exclude respondents who were under the age of 22 in 1983 (most Israelis serve in the army between the ages 18-21); the upper limit was set to include only individuals who had not reached formal retirement age ( 65 for men and 60 for women). Immigrants who had arrived in Israel before 1980 were also excluded from the sample.

\section{Work History Patterns: Diagrammatic Representation}

To describe and contrast the work history patterns of various groups (defined by gender, ethnicity, marital status, education level and age group) in the following sections, we employ a diagrammatic device developed by Corcoran (1979) to describe 
the work history patterns of US women; this diagrammatic representation was also used for a similar study of work history patterns of women in Great Britain (Steward and Greenhalgh, 1984).

No of spells

2

3

4

5

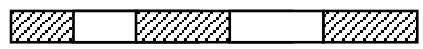

Currently Not Working

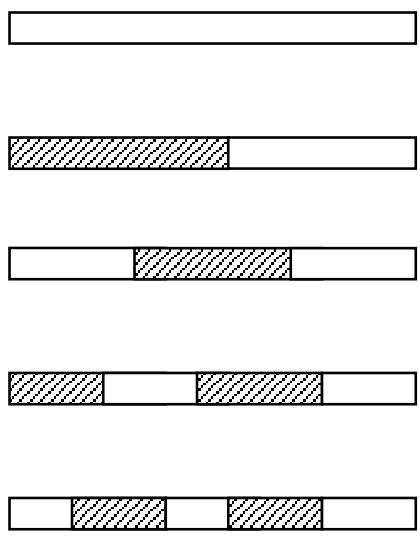

\section{Chart 1 \\ Typical Work History Patterns}

Note: Shaded areas of bars are continuous periods of work.

Non shaded areas of bars are periods of non-work, of at least one month.

Chart 1 shows typical work history patterns. The bars cover the 13-year period for which data are available, ending in December 1995. Work history patterns are divided into one of five categories, based on number of spells in and out of work. A shaded area in the bars represents a period of continuous work (in-spell), while a non-shaded area is a period of non-work (out-spell), of at least a month duration.

The left-hand side of the chart relates to individuals "currently" employed (in December 1995). Workers in the first category worked continuously over the 13-year period preceding December 1995 (one spell). Workers in the second category were not employed for a period (one out-spell), followed by continuous employment (inspell). In the third category (with three spells), continuous work is interrupted by a spell of non-work. Workers in the fourth (fifth) category experienced four (five) distinct spells of non-work and work. For workers in an additional category six (not shown in the chart), there were six or more separate spells of work and non-work. There may be some underestimation of the number and duration of non-work spells, to the extent that workers did not work for periods of less than one month. The righthand side of the chart is similar, but relates to individuals who were not working in December 1995.

While the approach in this study parallels that used by both Corcoran and by Stewart and Greenhalgh $(\mathrm{S} \& \mathrm{G})$, the data used in the present study are both more comprehensive and robust than those used in the previous ones. The earlier studies 
were strangely restrictive in scope, examining the work history patterns of women only, thus obviating gender comparisons (a central concern of the present paper). The work history data in the previous studies were collected by surveys and were based on the memory of respondents, a potential source of error; the present study uses objective data supplied by employers, generated on a month-by-month basis. Related to this, defined periods of non-work were lengthy in the earlier studies (one year in Corcoran and three months in S\&G), compared with one month in the present study, leading to greater accuracy in the measurement of non-work spells. On the other hand, the earlier studies ranged over the full period of potential work, since completing education; the present study is confined to a 13-year time horizon. The sample in the Corcoran study was restricted to individuals currently working while our dataset and that used by $S \& G$ includes both individuals currently working and those not working.

\section{Gender Differences in Work History Patterns}

As would be expected, our analysis shows considerable differences between the work history patterns of men and women (Table 1). Overall, during the 153 month period ending in December 1995, men worked 77.8 percent of the time on average, while women worked only 59.7 percent of the time. Current employment status (reported by the NII, as of December 1995) is seen to be an important core variable in explaining the percentage of time spent at work. Some 70 percent of men and 63 percent of women were currently employed in December 1995. Men classified as currently working had worked 89.3 percent of the time during the period of analysis, while men not working had worked only about half of the time (51.2 percent). The figures for women are lower: 78.3 for women currently employed and 28.1 percent for women not at work.

Table 1

Share of time spent in work or non-work during past 13 years (1983-1995), by gender

\begin{tabular}{|c|c|c|c|c|c|c|}
\hline & \multicolumn{3}{|c|}{ Men } & \multicolumn{3}{|c|}{ Women } \\
\hline & $\begin{array}{l}\text { Currently } \\
\text { employed }\end{array}$ & $\begin{array}{c}\text { Not } \\
\text { employed }\end{array}$ & All men & $\begin{array}{l}\text { Currently } \\
\text { employed }\end{array}$ & $\begin{array}{c}\text { Not } \\
\text { employed }\end{array}$ & $\begin{array}{c}\text { All } \\
\text { women }\end{array}$ \\
\hline $\begin{array}{l}\text { Number of } \\
\text { individuals in } \\
\text { sample }\end{array}$ & 72,720 & 31,520 & 104,240 & 69,750 & 41,143 & 110,893 \\
\hline Percentage & 69.8 & 30.2 & 100.0 & 62.9 & 37.1 & 100.0 \\
\hline $\begin{array}{l}\text { Share of time in } \\
\text { work }(\%)\end{array}$ & 89.3 & 51.2 & 77.8 & 78.3 & 28.1 & 59.7 \\
\hline $\begin{array}{l}\text { Share of time } \\
\text { not in work }(\%)\end{array}$ & 10.7 & 48.8 & 22.2 & 21.7 & 71.9 & 40.3 \\
\hline
\end{tabular}

A more detailed breakdown of work histories is provided by examining the number of successive spells of employment (in-spells) and non-work (out-spells), experienced by individuals in the sample. Table 2 provides information on the frequency distribution of the sample according to number of spells, for the four sub-groups identified thus far. It is seen that women experience more work interruptions than men.

Examining first individuals who were currently employed in December1995, over one third of men and less than 20 percent of women worked continuously during the 13- 
year period. One quarter of men and 17 percent of women experienced one interruption (only three spells), while over 40 percent of women and 23.6 percent of men had six or more spells (i.e. more than three out-spells). Overall, more than half of women had five or more spells compared with a third of men. Turning to the righthand side of the table, relating to individuals currently not in work, again it is seen that men experience more in-spells than women. Some 30 percent of women and only 18.2 percent of men never worked over the 13-year period. Nearly a quarter of men but only 6.8 percent of women worked without interruption until the current non-work spell.

Table 2

Frequency distribution of number of spells experienced, by gender (\%)

\begin{tabular}{|l|c|c|c|c|}
\hline \multirow{2}{*}{$\begin{array}{l}\text { Number of spells } \\
\text { (in-spells and out-spells) }\end{array}$} & \multicolumn{2}{|c|}{ Currently working } & \multicolumn{2}{c|}{ Not in work } \\
\cline { 2 - 5 } & Men & Women & Men & Women \\
\hline One spell & 34.0 & 18.9 & 18.2 & 30.3 \\
\hline Two spells & 3.6 & 5.7 & 23.8 & 6.8 \\
\hline Three spells & 25.0 & 17.4 & 4.0 & 9.5 \\
\hline Four spells & 3.4 & 7.1 & 17.6 & 7.8 \\
\hline Five spells & 10.3 & 10.6 & 3.5 & 7.3 \\
\hline Six spells or more & 23.6 & 40.3 & 32.8 & 38.2 \\
\hline Total & 100.0 & 100.0 & 100.0 & 100.0 \\
\hline
\end{tabular}

Charts 2 and 3 (based on Table 3 ) delve deeper by examining the timing and average duration of spells for the two groups - currently employed and not in work. The charts are parallel in format to Chart 1 . The relative size of each section of a bar (whether shaded or non-shaded) is equivalent to the share of that spell in the 13-year time period; these shares are marked below the relevant section of the bar, in each case. Overall, the charts confirm that men and women experience very different work histories. Not only are differences evident in the relative number of spells (Table 2) but there are differences by gender in the average duration of spells. Women experience more work interruptions and longer spells of non-work, than men. This basic difference holds for both the currently employed and non-employed subsamples.

While most of these results are both unsurprising and compatible with available labor force data, some of the findings are less expected. This is particularly the case with regard to the considerable amount of intermittent employment found amongst male workers. Moreover, women's labor market attachment, while less than men's, is stronger than is generally presumed. 
No. of spells

2

3

4

5

6+
Men:

Mean durations (\%)

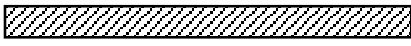

100
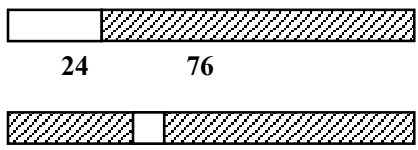

$\begin{array}{lll}29 & 8 & 63\end{array}$
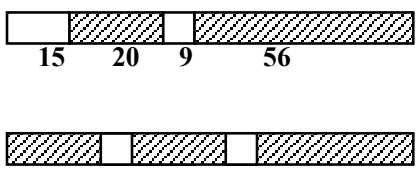

$\begin{array}{lllll}25 & 7 & 23 & 6 & 39\end{array}$

$\Sigma$ Work $=76$

$\Sigma$ Non Work $=24$
Women:

Mean durations (\%)

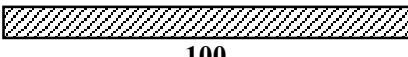

100
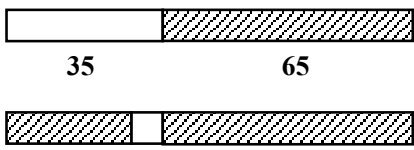

62

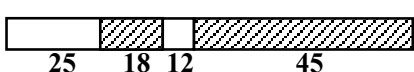

$\mathbb{W U} \mathbb{W} \mathbb{W} \mathbb{W} \mathbb{W}$

$\begin{array}{lllll}22 & 7 & 22 & 7 & 42\end{array}$

$\Sigma$ Work $=65$

$\Sigma$ Non Work $=35$

Chart 2

Work History Patterns of Men and Women Currently Working (1983-1995)

No. of spells

Men:

Mean durations (\%)

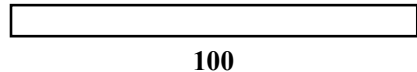

2



3

4

5

6+
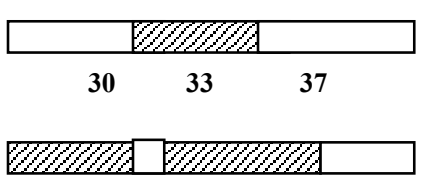

$\begin{array}{llll}29 & 9 & 39 & 23\end{array}$

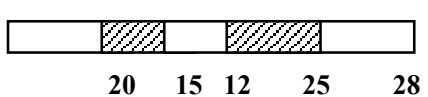

$\Sigma$ Work $=\mathbf{5 7}$

$\Sigma$ Non Work $=43$
Women:

Mean durations (\%)
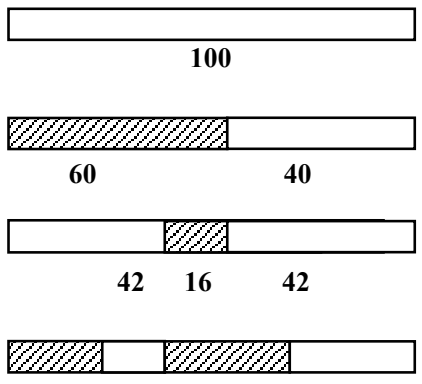

$\begin{array}{llll}28 & 12 & 31 & 29\end{array}$

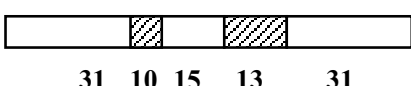

$\Sigma$ Work $=42$

$\Sigma$ Non Work $=58$

Chart 3

Work History Patterns of Men and Women Currently Not Working (1983-1995) 
The particular work history patterns depicted in Charts 2 and 3 are largely the outcome of the underlying composition of the sample. The sample contains individuals with differing marital status, age, education level and ethnic origin. All of these factors will contribute to the differentiated work history patterns for the subgroups in question. Indeed, on the basis of both economic theory and published data on labor force participation and employment rates by education, age and marital status, we would expect work histories also to differ significantly by marital status (and its interaction with gender), age group, ethnic origin and education; in the following four sections we present more detailed analyses of work histories, broken down by ethnic origin, marital status, age group and education. In order to keep the analysis within manageable proportions, in the remaining analyses in this paper we consider only the group of currently employed workers, clearly the more interesting sub-sample from a labor market point of view ${ }^{3}$.

Table 3

Relative spell durations, by gender

(\%)

\begin{tabular}{|c|c|c|c|c|c|}
\hline \multicolumn{3}{|c|}{ Currently working } & \multicolumn{3}{|c|}{ Not in work } \\
\hline Work history & Men & Women & Work history & Men & Women \\
\hline $\begin{array}{l}\text { One spell - } \\
\text { In-spell }\end{array}$ & 100 & 100 & $\begin{array}{l}\text { One spell - } \\
\text { out-spell }\end{array}$ & 100 & 100 \\
\hline $\begin{array}{c}\text { Two spells - } \\
\text { out-spell } \\
\text { in-spell }\end{array}$ & $\begin{array}{l}24 \\
76\end{array}$ & $\begin{array}{l}35 \\
65\end{array}$ & $\begin{array}{c}\text { Two spells - } \\
\text { in-spell } \\
\text { out-spell }\end{array}$ & $\begin{array}{l}73 \\
27\end{array}$ & $\begin{array}{l}60 \\
40\end{array}$ \\
\hline $\begin{array}{l}\text { Three spells - } \\
\text { in-spell } \\
\text { out-spell } \\
\text { in-spell } \\
\end{array}$ & $\begin{array}{c}29 \\
8 \\
63 \\
\end{array}$ & $\begin{array}{c}30 \\
8 \\
62 \\
\end{array}$ & $\begin{array}{c}\text { Three spells - } \\
\text { out-spell } \\
\text { in-spell } \\
\text { out-spell }\end{array}$ & $\begin{array}{l}30 \\
33 \\
37 \\
\end{array}$ & $\begin{array}{l}42 \\
16 \\
42 \\
\end{array}$ \\
\hline $\begin{array}{c}\text { Four spells - } \\
\text { out-spell } \\
\text { in-spell } \\
\text { out-spell } \\
\text { in-spell }\end{array}$ & $\begin{array}{c}15 \\
20 \\
9 \\
56\end{array}$ & $\begin{array}{l}25 \\
18 \\
12 \\
45\end{array}$ & $\begin{array}{c}\text { Four spells - } \\
\text { in-spell } \\
\text { out-spell } \\
\text { in-spell } \\
\text { out-spell }\end{array}$ & $\begin{array}{c}29 \\
9 \\
39 \\
23\end{array}$ & $\begin{array}{l}28 \\
12 \\
31 \\
29\end{array}$ \\
\hline $\begin{array}{c}\text { Five spells - } \\
\text { in-spell } \\
\text { out-spell } \\
\text { in-spell } \\
\text { out-spell } \\
\text { in-spell } \\
\end{array}$ & $\begin{array}{c}25 \\
7 \\
23 \\
6 \\
39 \\
\end{array}$ & $\begin{array}{c}22 \\
7 \\
22 \\
7 \\
42 \\
\end{array}$ & $\begin{array}{c}\text { Five spells - } \\
\text { out-spell } \\
\text { in-spell } \\
\text { out-spell } \\
\text { in-spell } \\
\text { out-spell }\end{array}$ & $\begin{array}{l}20 \\
15 \\
12 \\
25 \\
28\end{array}$ & $\begin{array}{l}31 \\
10 \\
15 \\
13 \\
31\end{array}$ \\
\hline $\begin{array}{l}\text { Six spells or } \\
\text { more }\end{array}$ & $\begin{array}{l}\text { Sum in-spells } \\
=76 \\
\text { Sum out-spells } \\
=24\end{array}$ & $\begin{array}{l}\text { Sum in-spells } \\
=65 \\
\text { Sum out-spells } \\
=35\end{array}$ & $\begin{array}{l}\text { Six spells or } \\
\text { more }\end{array}$ & $\begin{array}{l}\text { Sum in-spells } \\
=57 \\
\text { Sum out-spells } \\
=43\end{array}$ & $\begin{array}{l}\text { Sum in-spells } \\
=42 \\
\text { Sum out-spells } \\
=58\end{array}$ \\
\hline
\end{tabular}

\section{Work History Patterns by Ethnic Origin ${ }^{4}$}

Israel is largely an immigrant society. In the fifty years since statehood, the Jewish population has grown at an average annual rate of 4.1 percent with net migration accounting for about half of this growth. Over this period over two and a half million Jews immigrated to Israel; the Jewish population stood at 4.55 million at the end of 1995. Labor market indicators, such a participation rates, unemployment and relative 
wages, indicate that Sephardi (Eastern) Jews stemming from North Africa, the Middle East and Yemen fare less well in the labor market than their Ashkenazi (Western) counterparts - Jews coming from America and Europe.

To examine how far country of origin effects work history patterns, the sample (which excludes individuals who arrived in Israel after 1980) was divided into three country of origin groups. The Eastern group comprises individuals who were born in Asia or Africa or whose father had emigrated from these countries. Similarly, the Western group relates to individuals (or the father) who stemmed from Europe or America. The shares of these two groups of workers in the sample are similar, reflecting the relative size of these two groups in the population as a whole prior to the mass influx of immigrants from the former Soviet Union that began in the late 1980s. ${ }^{5}$ A third, smaller group contains individuals born in Israel and whose father too was born in Israel.

Tables 4 and 5, relating respectively to men and women currently working, confirm that overall the Eastern group is subject to greater labor market interruptions and shorter overall period in employment, than are the other two groups. The differences are particularly marked for women.

Table 4

Work histories for men currently employed, by ethnic origin (selected information)

\begin{tabular}{|l|c|c|c|c|}
\hline $\begin{array}{c}\text { Ethnic } \\
\text { Origin }\end{array}$ & $\begin{array}{c}\text { Total } \\
\text { number in } \\
\text { sample }\end{array}$ & $\begin{array}{c}\text { Continuosly } \\
\text { employed } \\
(\mathbf{1} \text { spell) } \\
(\mathbf{\%})\end{array}$ & $\begin{array}{c}\text { 5 or more } \\
\text { spells } \\
\mathbf{( \% )}\end{array}$ & $\begin{array}{c}\text { Share of } \\
\text { time in } \\
\text { work } \\
(\mathbf{\%})\end{array}$ \\
\hline Eastern & 35,464 & 28.4 & 38.4 & 88.3 \\
\hline Western & 32,214 & 39.2 & 29.2 & 90.6 \\
\hline Israel & 5,042 & 40.3 & 33.7 & 88.9 \\
\hline Total & 72,720 & 34.0 & 33.9 & 89.3 \\
\hline
\end{tabular}

Table 5

Work histories for women currently employed, by ethnic origin (selected information)

\begin{tabular}{|l|c|c|c|c|}
\hline $\begin{array}{c}\text { Ethnic } \\
\text { origin }\end{array}$ & $\begin{array}{c}\text { Total } \\
\text { number in } \\
\text { sample }\end{array}$ & $\begin{array}{c}\text { Continuosly } \\
\text { employed } \\
(\mathbf{1} \text { spell) } \\
\text { (\%) }\end{array}$ & $\begin{array}{c}\mathbf{5} \text { or more } \\
\text { spells } \\
\mathbf{( \% )}\end{array}$ & $\begin{array}{c}\text { Share of } \\
\text { time in } \\
\text { work } \\
\mathbf{( \% )}\end{array}$ \\
\hline Eastern & 32,994 & 14.1 & 56.1 & 74.3 \\
\hline Western & 31,768 & 23.3 & 45.5 & 82.2 \\
\hline Israel & 4,988 & 23.3 & 50.2 & 80.5 \\
\hline Total & 69,750 & 18.9 & 50.9 & 78.3 \\
\hline
\end{tabular}

Only minor differences are discerned between the Western and the (second generation) Israel groups. This result is expected. The fathers of the latter group were born in Israel prior to statehood (in 1948), at which time the small population 
consisted of mainly Jews of European origin. ${ }^{6}$ Differences in the work history patterns of Eastern and Western (and Israel) groups are the combined result of different average levels of human capital, differences in social norms and attitudes, and probably, also, discrimination.

The median of years of schooling for Western workers is 13.1 compared with 11.3 for Eastern workers. The difference is even more pronounced in terms of tertiary education: about a third of workers of Western origin and less than 10 percent of Eastern origin workers had at least some academic education (Central Bureau of Statistics, 1996). Eastern families are more traditional, have more children and retain more restrictions on female labor market activity. ${ }^{7}$ While it is difficult to document, Eastern workers probably face some degree of discrimination at the stages of hiring and layoffs, with the result of more interrupted work histories.

\section{The Effect of Marital Status}

A growing literature, particularly over the last two decades, has shown that the labor market and the marriage market are interconnected. In this spirit, the section examines work history patterns according to marital status - married workers, divorced and widowed workers and single workers. Of the 72,720 men currently working, some 92 percent were married (in 1995); divorced/widowed workers and single workers each constituted some 4 percent of the sample ${ }^{8}$. As expected, the parallel figures for working women differ from those relating to men: of the 69,750 employed women in the sample, 82 percent were married, 12 percent divorced/widowed and nearly 6 percent single. The effects of marital status on work patterns are shown in Tables 6, 7 and 8 .

Table 6 examines, for both men and women, the effect of marital status on the share of time over the 13 year period that each sub-sample was either employed or out of work. Married men worked most; they were in work for 90.0 percent of the period, compared with 84.9 percent for divorced/widowed men and only 78.8 percent for single men. A reverse pattern is seen for women. Married women worked least $(77.8$ percent of the time), divorced/widowed women worked rather more (78.5 percent of the time) and single women very much more ( 86.2 percent of the time). Male differences in work histories according to marital status can be explained, in part, by age differences (see next section for a discussion of age effects). Younger workers work less and single male workers tend to be younger than workers in the other two groups. However for women, age effects and marital status work in opposite directions; single women are the youngest, yet are employed for a larger share of the 13-year time period than the other two groups. Had age effects been kept constant for women, the differences between the three marital status groups would have been even greater. 
Table 6

Share of time spent in work or non-work by individuals currently employed, by gender and marital status

\begin{tabular}{|l|c|c|c|c|c|c|}
\hline \multirow{2}{*}{$\begin{array}{c}\text { Marital } \\
\text { status }\end{array}$} & $\begin{array}{c}\text { Number } \\
\text { in } \\
\text { sample }\end{array}$ & $\begin{array}{c}\text { Share of } \\
\text { time in } \\
\text { work } \\
(\%)\end{array}$ & $\begin{array}{c}\text { Share of } \\
\text { time not } \\
\text { in work } \\
(\%)\end{array}$ & $\begin{array}{c}\text { Number } \\
\text { in } \\
\text { sample }\end{array}$ & $\begin{array}{c}\text { Share of } \\
\text { time in } \\
\text { work } \\
(\%)\end{array}$ & $\begin{array}{c}\text { Share of } \\
\text { time not } \\
\text { in work } \\
(\%)\end{array}$ \\
\hline Married & 66,746 & 90.0 & 10.0 & 57,444 & 77.8 & 22.2 \\
\hline $\begin{array}{l}\text { Divorced \& } \\
\text { Widowed }\end{array}$ & 3,230 & 84.9 & 15.1 & 8,419 & 78.5 & 21.5 \\
\hline Single & 2,744 & 78.8 & 21.2 & 3,887 & 86.2 & 13.8 \\
\hline Total & 72,720 & 89.3 & 10.7 & 69,750 & 78.3 & 21.7 \\
\hline
\end{tabular}

Table 7

Frequency distribution of spells experienced for individuals currently in work, by gender and marital status

(\%)

\begin{tabular}{|l|c|c|c|c|c|c|}
\hline $\begin{array}{l}\text { Number of spells } \\
\text { (in-spells and } \\
\text { out-spells) }\end{array}$ & \multicolumn{3}{|c|}{ Men } & \multicolumn{3}{c|}{ Women } \\
\cline { 2 - 6 } & Married & $\begin{array}{l}\text { Divorced \& } \\
\text { widowed }\end{array}$ & Single & Married & $\begin{array}{l}\text { Divorced \& } \\
\text { widowed }\end{array}$ & Single \\
\hline One spell & 34.8 & 23.9 & 20.9 & 18.0 & 20.8 & 29.2 \\
\hline Two spells & 3.6 & 2.7 & 4.2 & 5.8 & 5.5 & 3.6 \\
\hline Three spells & 25.6 & 20.9 & 14.6 & 17.5 & 16.6 & 17.4 \\
\hline Four spells & 3.4 & 3.8 & 4.9 & 7.3 & 7.0 & 4.3 \\
\hline Five spells & 10.4 & 10.4 & 8.5 & 10.8 & 9.4 & 11.0 \\
\hline Six spells or more & 22.2 & 33.3 & 46.9 & 40.6 & 40.3 & 34.4 \\
\hline Total & 100.0 & 100.0 & 100.0 & 100.0 & 100.0 & 100.0 \\
\hline
\end{tabular}

Frequency distributions of the various work patterns (Table 7) provide more detailed information on the various work patterns. The table shows that the two groups with largest numbers in continuous employment (one spell) were married men and single women; single men and married women experienced the most interrupted work histories.

More than a third of married men and only 20.9 of single men worked without interruption over the 13 years. At the other extreme, almost half of all single men (46.9 percent) and less than a quarter of married men (22.2 percent), had six or more spells.

The table shows smaller differences by marital status for women and the pattern runs in the opposite direction. Almost 30 percent of single women and only 18 percent of married women worked continuously. Over 40 percent of married women and 34.4 percent of single women experienced six or more spells. As noted, even larger differences between the marital status groups for women would have been recorded had the effects of age been held constant. 
Table 8

Relative spell durations of those currently employed, by gender and marital status

(\%)

\begin{tabular}{|c|c|c|c|c|c|c|}
\hline \multirow[b]{2}{*}{ Work history } & \multicolumn{3}{|c|}{ Men } & \multicolumn{3}{|c|}{ Women } \\
\hline & Married & $\begin{array}{c}\text { Widowed \& } \\
\text { divorced }\end{array}$ & Single & Married & $\begin{array}{c}\text { Widowed \& } \\
\text { divorced }\end{array}$ & Single \\
\hline $\begin{array}{r}\text { One spell - } \\
\text { in-spell }\end{array}$ & 100 & 100 & 100 & 100 & 100 & 100 \\
\hline $\begin{array}{l}\text { Two spells - } \\
\text { out-spell } \\
\text { in-spell }\end{array}$ & $\begin{array}{l}22 \\
78\end{array}$ & $\begin{array}{l}40 \\
60\end{array}$ & $\begin{array}{l}38 \\
62\end{array}$ & $\begin{array}{l}36 \\
64\end{array}$ & $\begin{array}{l}33 \\
67\end{array}$ & $\begin{array}{l}17 \\
83\end{array}$ \\
\hline $\begin{array}{l}\text { Three spells - } \\
\text { in-spell } \\
\text { out-spell } \\
\text { in-spell }\end{array}$ & $\begin{array}{c}29 \\
8 \\
63\end{array}$ & $\begin{array}{c}33 \\
8 \\
59\end{array}$ & $\begin{array}{c}29 \\
9 \\
62\end{array}$ & $\begin{array}{c}30 \\
8 \\
62\end{array}$ & $\begin{array}{c}29 \\
8 \\
63\end{array}$ & $\begin{array}{c}32 \\
7 \\
61\end{array}$ \\
\hline $\begin{array}{l}\text { Four spells - } \\
\text { out-spell } \\
\text { in-spell } \\
\text { out-spell } \\
\text { in-spell }\end{array}$ & $\begin{array}{c}14 \\
20 \\
9 \\
57\end{array}$ & $\begin{array}{c}21 \\
21 \\
9 \\
48\end{array}$ & $\begin{array}{l}23 \\
18 \\
11 \\
47\end{array}$ & $\begin{array}{l}25 \\
18 \\
12 \\
45\end{array}$ & $\begin{array}{l}26 \\
16 \\
12 \\
46\end{array}$ & $\begin{array}{c}19 \\
23 \\
8 \\
50\end{array}$ \\
\hline $\begin{array}{l}\text { Five spells - } \\
\quad \text { in-spell } \\
\text { out-spell } \\
\text { in-spell } \\
\text { out-spell } \\
\text { in-spell }\end{array}$ & $\begin{array}{c}25 \\
6 \\
23 \\
6 \\
39\end{array}$ & $\begin{array}{c}27 \\
7 \\
22 \\
6 \\
37\end{array}$ & $\begin{array}{c}24 \\
7 \\
20 \\
8 \\
41\end{array}$ & $\begin{array}{c}22 \\
7 \\
22 \\
7 \\
42\end{array}$ & $\begin{array}{c}24 \\
7 \\
21 \\
6 \\
42\end{array}$ & $\begin{array}{c}25 \\
6 \\
21 \\
6 \\
43\end{array}$ \\
\hline $\begin{array}{l}\text { Six spells or } \\
\text { more }\end{array}$ & $\begin{array}{c}\text { Sum in-spells } \\
=77 \\
\text { Sum out-spells } \\
=23\end{array}$ & $\begin{array}{c}\text { Sum in-spells } \\
=71 \\
\text { Sum out-spells } \\
=29\end{array}$ & $\begin{array}{c}\text { Sum in-spells } \\
=67 \\
\text { Sum out-spells } \\
=33\end{array}$ & $\begin{array}{c}\text { Sum in-spells } \\
=64 \\
\text { Sum out-spells } \\
=36\end{array}$ & $\begin{array}{l}\text { Sum in-spells } \\
=64 \\
\text { Sum out-spells } \\
=36\end{array}$ & $\begin{array}{c}\text { Sum in-spells } \\
=72 \\
\text { Sum out-spells } \\
=28\end{array}$ \\
\hline
\end{tabular}

Parallel results are found in the duration of spells analysis (Table 8). Duration of inspells is highest for married men and lowest for single men; for the female sample, inspell duration is largest for single women and lowest for married women.

Our results, based on gender differences and marital status, are consistent with a now sizeable and growing literature on the economics of the household. We consider first the differing work history patterns of married men and married women. Specialization and time allocation models - first developed by Gary Becker (1973) and collected in Becker (1991) - view marriage as a partnership formed to coordinate and facilitate household production and consumption activities. Division of labor and specialization within the household increase its productivity and constitute a key source of gains from marriage. Thus, it is more efficient for women to specialize in home production, and for men to specialize in labor market activity, if women's earnings capacity is lower than that of men's. Since, in this case, wives will undertake a greater share of household work than their husbands, the result is that married men rank highest, and married women lowest, in terms of measures of labor force attachment (in the present case, duration of in-spells and number of work interruptions). ${ }^{9}$ 
We focus now on single men and women; single men have the weakest attachment to the labor market and single women the strongest. This stark difference in work history patterns may be explained by the same specialization theory presented by Becker, to account for the employment behavior of married couples. Married men tend to specialize in labor market activities, leaving household duties to the wife, and sharing income with her (a pure income effect). In contrast, single men do not usually share income with a partner and single women do not benefit from transferred income from a spouse. Moreover, since single women tend to have fewer household duties (such as childcare) compared to their married and divorced/widowed counterparts, they are freer to devote more time to paid employment.

\section{Age Group Analysis}

To examine the effect of age on work history patterns, the samples of currently working men and women are split into 5-year age groups: 35-40, 41-45, 46-50, 51-55 and 56-60. Since work histories for all age groups relate to the same 13-year period, the labor market effects of macroeconomic variables are kept constant for all the age groups, thus facilitating an analysis of pure age effects.

The share of time in work increases with age, for both men and women (Table 9). Men in the 35-40 age group (in 1995) worked for 85.7 percent of the 13 years: the share of work rises steadily with age, reaching 91.8 percent for workers in the 56-60 age group. For women, a parallel upward movement in time in work is shown in the table (74.4 percent for the 35-40 age group, rising to 83.9 percent for the 56-60 age group), but the figures are lower than for men, for all age groups, as expected.

Table 9

Share of time spent in work or non-work by individuals currently employed, by gender and age group

\begin{tabular}{|c|c|c|c|c|}
\hline \multirow{2}{*}{$\begin{array}{c}\text { Age } \\
\text { group }\end{array}$} & $\begin{array}{c}\text { Share of time } \\
\text { in work } \\
\mathbf{( \% )}\end{array}$ & $\begin{array}{c}\text { Share of time } \\
\text { not in work } \\
\mathbf{( \% )}\end{array}$ & $\begin{array}{c}\text { Share of time } \\
\text { in work } \\
\mathbf{( \% )}\end{array}$ & $\begin{array}{c}\text { Share of time } \\
\text { not in work } \\
\mathbf{( \% )}\end{array}$ \\
\hline $\mathbf{3 5 - 4 0}$ & 85.7 & 14.3 & 74.4 & 25.6 \\
\hline $\mathbf{4 1 - 4 5}$ & 89.5 & 10.5 & 76.6 & 23.4 \\
\hline $\mathbf{4 6 - 5 0}$ & 90.9 & 9.1 & 80.3 & 19.7 \\
\hline $\mathbf{5 1 - 5 5}$ & 91.3 & 8.7 & 82.5 & 17.5 \\
\hline $\mathbf{5 6 - 6 0}$ & 91.8 & 8.2 & 83.9 & 16.1 \\
\hline Total & 89.3 & 10.7 & 78.3 & 21.7 \\
\hline
\end{tabular}

More evidence on the tendency for more continuous employment at higher ages is provided in Table 10, presenting the frequency distribution of spells by age group and gender. The percentage of workers in continuous employment (one spell) rises steadily with age, from 24.9 percent for the 35-40 age group to 40.9 percent for the 55-60 age group; for the female sample, the comparable figures are 11.7 percent and 31.2 percent, representing an even steeper increase with age than for men.

At the other extreme (six or more spells) the pattern is reversed, showing greater continuity of employment for older workers. Nearly 40 percent of younger male 
workers experience six or more spells, compared with only 15 percent for the oldest group. Again, more women than men had interrupted work histories (six or more spells), with the figures falling as age group rises (nearly 55 percent of younger women, compared with a quarter of older women). A detailed examination of the relative duration of periods of work and non-work, parallel to Tables 3 and 8 did not indicate notable differences by age ${ }^{10}$.

Table 10

Frequency distribution of spells experienced for individuals currently in work, by gender and age group

\begin{tabular}{|c|c|c|c|}
\hline \multirow{2}{*}{$\begin{array}{c}\text { Number of spells } \\
\text { (in-spells and } \\
\text { out-spells) }\end{array}$} & \multicolumn{3}{|c|}{$\begin{array}{c}\text { Frequency distribution of sample in each } \\
\text { spell category }(\%)\end{array}$} \\
\hline & $\begin{array}{l}\text { Age } \\
\text { group }\end{array}$ & Men & Women \\
\hline One spell & $\begin{array}{l}35-40 \\
41-45 \\
46-50 \\
51-55 \\
56-60\end{array}$ & $\begin{array}{l}24.9 \\
35.1 \\
37.3 \\
38.3 \\
40.9\end{array}$ & $\begin{array}{l}11.7 \\
15.9 \\
21.4 \\
26.5 \\
31.2\end{array}$ \\
\hline Two spells & $\begin{array}{l}35-40 \\
41-45 \\
46-50 \\
51-55 \\
56-60\end{array}$ & $\begin{array}{l}4.9 \\
3.6 \\
3.0 \\
2.9 \\
2.6\end{array}$ & $\begin{array}{l}4.0 \\
5.9 \\
6.7 \\
6.7 \\
6.0\end{array}$ \\
\hline Three spells & $\begin{array}{l}35-40 \\
41-45 \\
46-50 \\
51-55 \\
56-60\end{array}$ & $\begin{array}{l}17.2 \\
25.4 \\
29.0 \\
29.5 \\
28.7\end{array}$ & $\begin{array}{l}12.6 \\
16.8 \\
19.7 \\
21.2 \\
21.7\end{array}$ \\
\hline Four spells & $\begin{array}{l}35-40 \\
41-45 \\
46-50 \\
51-55 \\
56-60\end{array}$ & $\begin{array}{l}4.9 \\
3.3 \\
2.9 \\
2.7 \\
2.3\end{array}$ & $\begin{array}{l}6.4 \\
7.7 \\
8.0 \\
6.9 \\
6.4\end{array}$ \\
\hline Five spells & $\begin{array}{l}35-40 \\
41-45 \\
46-50 \\
51-55 \\
56-60\end{array}$ & $\begin{array}{l}10.5 \\
10.4 \\
10.2 \\
10.3 \\
10.2\end{array}$ & $\begin{array}{c}10.5 \\
11.4 \\
10.9 \\
9.6 \\
9.4\end{array}$ \\
\hline Six spells or more & $\begin{array}{l}35-40 \\
41-45 \\
46-50 \\
51-55 \\
56-60\end{array}$ & $\begin{array}{l}37.6 \\
22.1 \\
17.6 \\
16.4 \\
15.2\end{array}$ & $\begin{array}{l}54.8 \\
42.3 \\
33.2 \\
28.9 \\
25.4\end{array}$ \\
\hline Total & $\begin{array}{l}35-40 \\
41-45 \\
46-50 \\
51-55 \\
56-60\end{array}$ & $\begin{array}{l}100.0 \\
100.0 \\
100.0 \\
100.0 \\
100,0\end{array}$ & $\begin{array}{l}100.0 \\
100.0 \\
100.0 \\
100.0 \\
100,0\end{array}$ \\
\hline
\end{tabular}

How may these differences in work histories by age group be explained? The differing work history patterns displayed for the various age groups may stem from various sources, in particular cohort effects and life cycle effects. It is not easy to identify the relative incidence of these two effects. 
The sample represents five different age cohorts. Work values may differ for each cohort. Early on in their working careers, older workers may have been exposed to a different working environment than is current in the labor market for younger workers. Accepted work norms in the past may have given more emphasis to employment stability and long commitment to the same employer; older workers may still retain these work values. Again, work contracts have changed significantly in recent years, particularly affecting younger workers. There is a steady move away from tenured, standard contracts to temporary and individual contracts, especially affecting younger groups. The number of workers attached to employment agencies (again mainly affecting the young) is growing fast. The share of unionized workers in the labor force has declined in recent years ${ }^{11}$, and it is likely that the incidence of union membership (and thus working under a collective bargaining contract) is greater amongst older workers, leading to more stable employment of older workers.

But life cycle effects no doubt also play a role in differentiating between the work history patterns of older and younger workers. Younger workers are more open to change and display a greater willingness to switch employers. The opportunity costs of a job change are lower for younger workers, given their lower wages and higher probability of finding a new job. The labor market imposes major difficulties on older workers wishing to find new employment; in addition, older workers are more conservative, staid in their ways and generally less inclined to move jobs.

\section{The Role of Education}

Tables 11 and 12, relating respectively to men and women currently working, indicate that for both sexes, the less educated groups are subject to greater labor market interruptions and shorter overall period in employment, than are better educated groups. The differences between the three education groups are particularly marked for women. Nearly 43 per cent of males with $0-8$ years of schooling experienced five or more spells, compared with only 30 percent of men with 13 or more years of schooling; for women the corresponding figures are 57 per cent and 48 per cent, respectively.

The total share of the 13-year time period that women spent in employment rises from 69 percent for the lowest educated group to 84 percent for the highest; for men, there is little deviation around the overall average of 89 percent, with a slight upward trend with additional education. Since the more educated workers are most probably younger than average, the underlying positive effect of education on employment continuity is partly offset by the negative effect of the younger age; regression analysis to be presented in section 9 will provide estimates of net effects. 
Table 11

Work histories for men currently employed, by level of education (selected information)

\begin{tabular}{|l|c|c|c|c|}
\hline $\begin{array}{c}\text { Years of } \\
\text { schooling }\end{array}$ & $\begin{array}{c}\text { Total } \\
\text { number in } \\
\text { sample }\end{array}$ & $\begin{array}{c}\text { Continuosly } \\
\text { employed } \\
\text { (1 spell) } \\
(\mathbf{\%})\end{array}$ & $\begin{array}{c}\text { 5 or more } \\
\text { spells } \\
\mathbf{( \% )}\end{array}$ & $\begin{array}{c}\text { Share of } \\
\text { time in } \\
\text { work } \\
(\mathbf{\%})\end{array}$ \\
\hline $\mathbf{0 - 8}$ years & 8,968 & 24.9 & 42.7 & 86.3 \\
\hline 9-12 years & 34,409 & 33.4 & 34.9 & 89.2 \\
\hline 13+ years & 29,343 & 37.6 & 30.1 & 90.4 \\
\hline Total & 72,720 & 34.0 & 33.9 & 89.3 \\
\hline
\end{tabular}

Table 12

Work histories for women currently employed, by level of education (selected information)

\begin{tabular}{|c|c|c|c|c|}
\hline $\begin{array}{c}\text { Years of } \\
\text { schooling }\end{array}$ & $\begin{array}{c}\text { Total } \\
\text { number in } \\
\text { sample }\end{array}$ & $\begin{array}{c}\text { Continuosly } \\
\text { employed } \\
\text { (1 spell) } \\
(\%)\end{array}$ & $\begin{array}{c}5 \text { or more } \\
\text { spells } \\
(\%)\end{array}$ & $\begin{array}{c}\text { Share of } \\
\text { time in } \\
\text { work } \\
(\%)\end{array}$ \\
\hline $0-8$ years & 8,497 & 11.8 & 57.1 & 69.2 \\
\hline 9-12 years & 31,200 & 18.8 & 51.7 & 75.6 \\
\hline $13+$ years & 30,053 & 21.1 & 48.3 & 83.8 \\
\hline Total & 69,750 & 18.9 & 50.9 & 78.3 \\
\hline
\end{tabular}

\section{Multivariate Analysis}

The sample breakdown used in this paper, by marital status, ethnic group, age and education, focuses our attention, separately, on each of these socioeconomic dimensions. However the observed effects are not net ones, as none of the other variables are held constant. The results of regression analysis can point to the direction, magnitude and significance of the effect of each of the variables, on the number of spells and the share of time in employment. Using a multiple regressions model, particular attention is now given to the net effect on intermittent employment (and non-work) of gender, age, marital status, ethnicity, and education, holding constant other socio-economic and control variables. These include: occupation, region of residence, place of residence, number of years since immigration (for non Israeli born workers) and number of cars owned by the household. The regression analyses presented in this section, complement the more descriptive results presented above.

Table 13 reports the effects of marital status, ethnic origin, age and education on the number of spells experienced over the 13-year time period. Table 14 presents results (for the same variables) from a regression employing 'total number of months employed' as the dependent variable. Separate regressions are run for men and women.

Marital status is defined by three dummy variables: married, divorced or widowed, with single as the reference group. The ethnic origin is either Eastern or 
Western/Israel (the reference group); the Westerner and Israeli sub-groups are combined as they are very similar in terms of socio-economic characteristics and work histories). Dummy variables are used for different age groups: ages 41-45, $46-50,51-55,56-60$, with the age group $35-40$ as the base group. The use of age dummy variables, rather than a continuous age variable, is preferable as it allows for a non- linear and non-monotonic effect of age. The age intervals are the same as those used in the descriptive analysis (Tables 9 and 10). Similar considerations underlie the definition of education by dummy variables rather than a continuous variable of number of years of schooling. Three dummies are used: 9-12 years of schooling, 13+ years and 0-8 years as the reference group.

\section{Number of spells regressions}

We turn first to the 'number of spells' regressions (Table 12): the overall picture emerging from the results is broadly similar to that from the descriptive analysis.

Table 12

Number of spells regressions: Men and women currently employed

\begin{tabular}{|c|c|c|c|c|}
\hline \multirow[t]{2}{*}{ Independent variables } & \multicolumn{2}{|c|}{ Men } & \multicolumn{2}{|c|}{ Women } \\
\hline & Coefficient & t-statistic & Coefficient & t-statistic \\
\hline $\begin{array}{l}\text { Marital status } \\
\text { (Single, in constant term): } \\
\text { Married } \\
\text { Divorced/widowed }\end{array}$ & $\begin{array}{l}-0.705 \\
-0.192\end{array}$ & $\begin{array}{c}17.14 \\
3.52\end{array}$ & $\begin{array}{l}0.486 \\
0.517\end{array}$ & $\begin{array}{l}14.27 \\
13.22\end{array}$ \\
\hline $\begin{array}{l}\text { Country of origin } \\
\text { (Western, in constant term): } \\
\text { Eastern }\end{array}$ & 0.159 & 9.16 & 0.133 & 7.67 \\
\hline $\begin{array}{l}\text { Age group } \\
\text { (Age group 35-40, in constant term): } \\
\text { Age group 41-45 } \\
\text { Age group 46-50 } \\
\text { Age group 51-55 } \\
\text { Age group 56-60 }\end{array}$ & $\begin{array}{l}-0.713 \\
-1.019 \\
-1.124 \\
-1.293\end{array}$ & $\begin{array}{l}33.91 \\
43.38 \\
41.99 \\
42.81\end{array}$ & $\begin{array}{l}-0.504 \\
-1.007 \\
-1.377 \\
-1.630\end{array}$ & $\begin{array}{l}24.76 \\
43.91 \\
51.52 \\
52.19\end{array}$ \\
\hline $\begin{array}{l}\text { Years of schooling } \\
\text { (0-8 years, in constant term): } \\
9-12 \text { years of schooling } \\
13+\text { years of schooling }\end{array}$ & $\begin{array}{l}-0.449 \\
-0.533\end{array}$ & $\begin{array}{l}17.57 \\
18.23\end{array}$ & $\begin{array}{l}-0.404 \\
-0.409\end{array}$ & $\begin{array}{l}15.07 \\
13.23\end{array}$ \\
\hline R-squared & \multicolumn{2}{|c|}{0.0878} & \multicolumn{2}{|c|}{0.1042} \\
\hline Number of observations & \multicolumn{2}{|c|}{62,778} & \multicolumn{2}{|c|}{61,127} \\
\hline
\end{tabular}

Note: Sample sizes drop due to missing values for some of the explanatory variables. Each of the regressions includes the following explanatory variables: occupation, region of residence, site of place of residence, foreign born $(=1)$, number of years in Israel (for foreign born), and number of cars in household. Information on all variables (definition, means and regression coefficients) is available from the authors.

Single men (the reference group) experience the largest number of spells: on average, divorced/widowed men have 0.19 fewer spells, and married men 0.71 spells less. While these coefficients are highly significant, the size is not large. These findings are reversed for women: single women have fewer spells than either married or 
divorced/widowed female workers (each with about half a spell more). Both Eastern men and women have more spells than their Western counter: however, the differences are very small ( 0.16 spells for men and 0.13 for women).

Age has the most pronounced effect on number of spells experiences over the 13-year time period, particularly so for women; number of spells decreases with age. Men in the 56-60 age group have 1.29 spells fewer than men aged 35-40; the parallel figure for women is 1.63. Finally, the number of spells experienced decreases with level of schooling; similar results are shown for men and women. Workers with over eight years of schooling experience about half a spell less than workers in the 0-8 years of schooling group.

A major shortcoming of the use of number of spells to measure intermittent employment is that it does not take account of the duration of the spells, both in and out of employment. This lacuna is addressed in the regressions reported subsequently.

\section{Length of time in employment regressions}

Detailed information of the duration of each spell in employment is used to calculate the total number of months of employment over the period 1983-1995. This measure is employed as the dependent variable in the regressions reported in Table 13. The coefficients reported in the table measure the effects of the independent variables on "months of employment" experienced over the 13-year time period. The results are generally supportive of those presented in Table 12.

Table 13

Length of time in employment regressions (months): Men and women currently employed

\begin{tabular}{|c|c|c|c|c|}
\hline \multirow[t]{2}{*}{ Independent variables } & \multicolumn{2}{|c|}{ Men } & \multicolumn{2}{|c|}{ Women } \\
\hline & Coefficient & t-statistic & Coefficient & t-statistic \\
\hline $\begin{array}{l}\text { Marital status } \\
\text { (Single, in constant term): } \\
\text { Married } \\
\text { Divorced/widowed }\end{array}$ & $\begin{array}{c}14.117 \\
5.958\end{array}$ & $\begin{array}{c}29.55 \\
9.43\end{array}$ & $\begin{array}{l}-15.199 \\
-13.623\end{array}$ & $\begin{array}{c}24.11 \\
18.82\end{array}$ \\
\hline $\begin{array}{l}\text { Country of origin } \\
\text { (Western and Israel, in constant term): } \\
\text { Eastern }\end{array}$ & -0.428 & 2.12 & -1.982 & 6.18 \\
\hline $\begin{array}{l}\text { Age group } \\
\text { (Age group 35-40, in constant term): } \\
\text { Age group 41-45 } \\
\text { Age group 46-50 } \\
\text { Age group 51-55 } \\
\text { Age group 56-60 }\end{array}$ & $\begin{array}{c}5.883 \\
8.833 \\
9.750 \\
11.391\end{array}$ & $\begin{array}{l}24.09 \\
32.36 \\
31.35 \\
32.45\end{array}$ & $\begin{array}{l}4.491 \\
10.527 \\
16.993 \\
21.337\end{array}$ & $\begin{array}{l}11.92 \\
24.80 \\
34.15 \\
36.91\end{array}$ \\
\hline $\begin{array}{l}\text { Years of schooling } \\
\text { (0-8 years, in constant term): } \\
9-12 \text { years of schooling } \\
13+\text { years of schooling }\end{array}$ & $\begin{array}{l}4.722 \\
5.149\end{array}$ & $\begin{array}{l}15.88 \\
15.17\end{array}$ & $\begin{array}{c}7.484 \\
13.450\end{array}$ & $\begin{array}{l}15.08 \\
23.54\end{array}$ \\
\hline R-squared & \multicolumn{2}{|c|}{0.0766} & \multicolumn{2}{|c|}{0.1330} \\
\hline Number of observations & \multicolumn{2}{|c|}{62,778} & \multicolumn{2}{|c|}{61,127} \\
\hline
\end{tabular}

Note: See note to Table 12 . 
Out of a maximum total of 153 months, married men work 14 months more than single men; divorced/widowed men work six months more than single men. As in the "number of spells" regressions, we find again the reverse picture for women: single women work 15 months more than married women and nearly 14 months more than divorced/widowed women. The effect of ethnic origin on total duration of employment is significant but negligible. Eastern men work 0.4 of a month less than men of Western/Israeli origin; the corresponding figure for Eastern women is about two months less.

The age variables have the strongest effect on the dependent variable. Employment duration rises consistently with age group. For male workers, those in the youngest (30-35 year) age group work less than workers in the other five-year interval groups: 6, 9, 10 and 11 months, respectively. Employment duration for women is affected more by age than men (except for the 41-45 age group); the differences for women are 4, 10, 17 and 21 months, respectively, compared to the youngest group. The gender differences are evidently related to the presence of young children in the household, which decreases as age advances. Finally, the positive effect of schooling on employment duration is stronger for women than men. Women who have completed 13 or more years of schooling work over 13 months more than women with 0-8 years of schooling; for men the corresponding figure is only 5 months. Women with high-school education work 7 months, and men 5 months, longer than coworkers in the lowest education group.

\section{Discussion}

This study has examined the extent, duration and timing of employment breaks amongst a large representative sample of Jewish workers in Israel over the 13-year time period, 1983-1995. Work histories were constructed from a new joint database, unique in Israel, which was derived from a linkage of 1995 Population Census data with monthly employment records of the National Insurance Institute. The paper focuses on gender differences in work history patterns and, within each gender, breakdowns are provided by ethnic origin, marital status, age and education level.

While there is now a substantial literature measuring the extent and effects of intermittent employment, these studies have focused almost entirely on the United States labour market. In probing these issues in a different country context, the present paper, and the ongoing research based on the new data set, will hopefully make a valid contribution to the study of labour markets, in a comparative context. Most of the findings presented in this paper are both compatible with current economic theories of household behavior and supportive of empirical findings for the United States and some European countries.

The study, in particular, highlights the considerable amount of intermittent employment found amongst Israeli male workers and also the stronger labor market attachment for women than is generally presumed. Gender differences in employment interruptions are greater for younger than older workers.

In ongoing research, the new measures of the extent and timing of employment breaks in Israel are being used as explanatory variables in a number of multivariable models, 
aimed at explaining various labor force phenomena. Empirical studies, using Mincertype earnings functions, show that a variable measuring years of labor market experience has considerable explanatory power in accounting for earnings differentials across individuals. But because available data sets in Israel do not contain information on work histories, only proxy measures of years of experience (based on age and years of schooling) have been used until now. The legitimacy of this proxy variable depends on the absence of employment breaks, an assumption that was thought to be acceptable for men but not women. Evidence from the USA (for example, Mincer and Polachek 1974, Mincer and Ofek 1982 and Light and Ureta 1995), from the UK (Joshi, 1987), and now from this paper, shows that women, particularly married women, do exhibit greater employment intermittence than men. Because of the greater unreliability of proxy measures of labor market experience for women, many empirical labor market studies in Israel have limited their focus to males only.

But in addition, our results show that male intermittent employment is also sizeable, indicating that work history information should be taken into account also in empirical research confined to males, where labor force experience is used as an explanatory variable. Our new data set provides a more reliable measure of employment experience in Israel than has been available until now, albeit though limited to a 13-year time period.

A particular focus of our current work is the effects of intermittent employment on human capital investments. In a now classic paper, Mincer and Polachek (1974) argued that women earn less than men because women's human capital investment depreciates from non-use during their longer period (on average) of withdrawal from employment. A related issue is the relationship between employment breaks and career choice. In some occupations, work breaks may result in large penalties since these occupations require constant updating (medicine, law, computers); in others, (school teaching for example) established salary scales are related to years of seniority (experience) without penalties for periods outside the labor force. Our new data set is being used to probe these, and complementary human capital investment, issues in the Israeli context. 


\section{References}

Becker, Gary (1973). “A Theory of Marriage: Part I”, Journal of Political Economy, 8 (4) August

Becker, Gary (1991). A Treatise on the Family, Cambridge, MA: Cambridge University Press (enlarged edition)

Borus, M. E. (1977). "A Cost-Effective Comparison of Vocational Training for Youth in Developing Countries: A Case Study of Four Training Modes in Israel”, Comparative Education Review, February

Central Bureau of Statistics (1996). Statistical Abstract of Israel

Cohen, Yinon, Yitchak Haberfeld, Guy Mundlak and Yitchak Saporta (2001).

Unionization Rate and the Coverage of Collective Agreements. Jerusalem: Ministry of Labour and Social Affairs

Corcoran, Mary E. (1979). "Work Experience, Labor Force Withdrawals and Women's Wages: Empirical Results Using the 1976 Panel of Income Dynamics”, In: Cynthia B. Lloyd, E. S. Andrews and C. L. Gilroy, eds., Women in the Labor Market. New York: Columbia University Press

Grossbard-Schectman, Amyra (1984). "A Theory of the Allocation of Time in Markets for Labor and Marriage", Economic Journal, 94, December

Joshi. H. (1987). “The Cash Opportunity Costs of Child-Bearing”, Economic Policy Research Unit Discussion Paper 208, London

International Labour Office. Bulletin of Labour Statistics, Geneva (various issues)

Light, Audrey and Manuelita Ureta (1995). "Early-Career Work Experiences and Gender Differentials", Journal of Labour Economics, 13 (1)

Lundberg, Shelly and Robert A. Pollak (1993). "Separate Spheres Bargaining and the Marriage Market”, Journal of Political Economy, 101 (6), December

Manser, Marilyn and Murray Brown (1990). "Marriage and Household DecisionMaking: A Bargaining Approach", International Economic Review, 22(2), June

Mincer, Jacob and Solomon Polachek (1974). "Family Investments in Human Capital: Earnings of Women", Journal of Political Economy, 82 (2).

Mincer, Jacob and Haim Ofek (1982). "Interrupted Work Careers: Depreciation and Restoration of Human Capital", Journal of Human Resources, 17 (1).

Neuman, Shoshana (2004). "Aliyah to Israel: Immigration Under Conditions of Adversity", in Klaus Zimmerman (ed.): European Migration: What Do We Know? Oxford University Press 
Neuman, Shoshana and Adrian Ziderman (2003). Work Histories of Israeli Men and Women. 1983-1995. Discussion Paper Series No. 6-2003. Tel Aviv: The Pinhas Sapir Center for Development, Tel Aviv University (August)

Steir, Haya (1998). "Short-term Employment Transitions of Women in the Israeli Labor Force", Industrial and Labor Relations Review, 51 (2)

Stewart, Mark B. and Christine A. Greenhalgh (1984). "Work History Patterns and the Occupational Attainment of Women”, Economic Journal, 94 ( ) September

Ziderman, Adrian (1989). "Training Alternatives for Youth: Results from Longitudinal Data", Comparative Education Review, 33 (2) 


\section{Appendix Tables}

Appendix Table 1

Frequency distribution of spells experienced for individuals currently in work, by gender and country of origin

(\%)

\begin{tabular}{|l|c|c|c|c|c|c|}
\hline $\begin{array}{l}\text { Number of } \\
\text { spells } \\
\text { (in-spells } \\
\text { and out- } \\
\text { spells) }\end{array}$ & \multicolumn{3}{|c|}{ Men } & \multicolumn{3}{|c|}{ Women } \\
\cline { 2 - 7 } & Africa/Asia & Europe/America & Israel & Africa/Asia & Europe/America & Israel \\
\hline One spell & 18.9 & 29.9 & 26.4 & 8.3 & 15.8 & 14.7 \\
\hline Two spells & 1.9 & 3.0 & 3.3 & 3.3 & 3.9 & 3.4 \\
\hline Three spells & 18.1 & 17.8 & 11.1 & 9.6 & 12.8 & 8.9 \\
\hline Four spells & 2.2 & 2.6 & 2.6 & 4.7 & 4.3 & 3.9 \\
\hline Five spells & 7.3 & 7.3 & 6.2 & 5.9 & 7.7 & 6.4 \\
\hline $\begin{array}{l}\text { Six spells or } \\
\text { more }\end{array}$ & 18.3 & 14.3 & 15.8 & 27.1 & 23.1 & 25.3 \\
\hline Total & 100.0 & 100.0 & 100.0 & 100.0 & 100.0 & 100.0 \\
\hline
\end{tabular}

Appendix Table 2

Frequency distribution of spells experienced for individuals currently not in work, by gender and country of origin

(\%)

\begin{tabular}{|l|c|c|c|c|c|c|}
\hline $\begin{array}{l}\text { Number of } \\
\text { spells } \\
\text { (in-spells } \\
\text { and out- } \\
\text { spells) }\end{array}$ & \multicolumn{3}{|c|}{ Men } & \multicolumn{3}{|c|}{ Women } \\
\cline { 2 - 7 } & Africa/Asia & Europe/America & Israel & Africa/Asia & Europe/America & Israel \\
\hline One spell & 5.1 & 5.1 & 10.4 & 12.9 & 9.1 & 12.1 \\
\hline Two spells & 6.8 & 7.4 & 8.8 & 2.0 & 3.1 & 3.0 \\
\hline Three spells & 1.3 & 1.0 & 1.6 & 4.1 & 2.9 & 3.0 \\
\hline Four spells & 6.6 & 4.1 & 3.4 & 2.8 & 3.1 & 2.7 \\
\hline Five spells & 1.2 & 0.9 & 1.2 & 3.2 & 2.2 & 2.3 \\
\hline $\begin{array}{l}\text { Six spells or } \\
\text { more }\end{array}$ & 12.1 & 7.3 & 8.9 & 16.1 & 11.8 & 14.1 \\
\hline Total & 100.0 & 100.0 & 100.0 & 100.0 & 100.0 & 100.0 \\
\hline
\end{tabular}


Appendix Table 3

Relative spell durations for the currently employed, by gender and country of origin

(\%)

\begin{tabular}{|c|c|c|c|c|c|c|}
\hline \multirow[b]{2}{*}{ Work history } & \multicolumn{3}{|c|}{ Men } & \multicolumn{3}{|c|}{ Women } \\
\hline & Africa/Asia & Europe/America & Israel & Africa/Asia & Europe/America & Israel \\
\hline $\begin{array}{l}\text { One spell - } \\
\text { in-spell }\end{array}$ & 100 & 100 & 100 & 100 & 100 & 100 \\
\hline $\begin{array}{l}\text { Two spells - } \\
\text { out-spell } \\
\text { in-spell }\end{array}$ & $\begin{array}{l}21 \\
79\end{array}$ & $\begin{array}{l}25 \\
75\end{array}$ & $\begin{array}{l}29 \\
71\end{array}$ & $\begin{array}{l}41 \\
59\end{array}$ & $\begin{array}{l}30 \\
70 \\
\end{array}$ & $\begin{array}{l}28 \\
72\end{array}$ \\
\hline $\begin{array}{l}\text { Three spells- } \\
\text { in-spell } \\
\text { out-spell } \\
\text { in-spell } \\
\end{array}$ & $\begin{array}{c}25 \\
8 \\
67 \\
\end{array}$ & $\begin{array}{c}33 \\
8 \\
59 \\
\end{array}$ & $\begin{array}{c}40 \\
8 \\
52\end{array}$ & $\begin{array}{c}27 \\
8 \\
65\end{array}$ & $\begin{array}{c}32 \\
8 \\
60\end{array}$ & $\begin{array}{c}37 \\
8 \\
55\end{array}$ \\
\hline $\begin{array}{l}\text { Four spells - } \\
\text { out-spell } \\
\text { in-spell } \\
\text { out-spell } \\
\text { in-spell }\end{array}$ & $\begin{array}{c}13 \\
18 \\
8 \\
61 \\
\end{array}$ & $\begin{array}{c}16 \\
22 \\
9 \\
52 \\
\end{array}$ & $\begin{array}{c}17 \\
23 \\
9 \\
51\end{array}$ & $\begin{array}{l}27 \\
16 \\
12 \\
25\end{array}$ & $\begin{array}{l}22 \\
21 \\
11 \\
46\end{array}$ & $\begin{array}{l}24 \\
21 \\
13 \\
42 \\
\end{array}$ \\
\hline $\begin{array}{c}\text { Five spells - } \\
\text { in-spell } \\
\text { out-spell } \\
\text { in-spell } \\
\text { out-spell } \\
\text { in-spell } \\
\end{array}$ & $\begin{array}{c}23 \\
7 \\
23 \\
6 \\
40 \\
\end{array}$ & $\begin{array}{c}27 \\
6 \\
22 \\
6 \\
38 \\
\end{array}$ & $\begin{array}{c}28 \\
6 \\
20 \\
7 \\
39 \\
\end{array}$ & $\begin{array}{c}20 \\
7 \\
21 \\
7 \\
44 \\
\end{array}$ & $\begin{array}{c}24 \\
7 \\
23 \\
7 \\
40 \\
\end{array}$ & $\begin{array}{c}27 \\
6 \\
20 \\
8 \\
39\end{array}$ \\
\hline $\begin{array}{l}\text { Six spells or } \\
\text { more }\end{array}$ & $\begin{array}{c}\text { Sum in-spells } \\
=75 \\
\text { Sum out-spells } \\
=25\end{array}$ & $\begin{array}{c}\text { Sum in-spells } \\
=77 \\
\text { Sum out-spells } \\
=23\end{array}$ & $\begin{array}{l}\text { Sum in-spells } \\
=75 \\
\text { Sum out-spells } \\
=25\end{array}$ & $\begin{array}{l}\text { Sum in-spells } \\
\quad=62 \\
\text { Sum out-spells } \\
=38\end{array}$ & $\begin{array}{c}\text { Sum in-spells } \\
=68 \\
\text { Sum out-spells } \\
=32\end{array}$ & $\begin{array}{c}\text { Sum in-spells } \\
=67 \\
\text { Sum out-spells } \\
=33\end{array}$ \\
\hline
\end{tabular}


Appendix Table 4

Relative spell durations for those currently not in work, by gender and country of origin

(\%)

\begin{tabular}{|c|c|c|c|c|c|c|}
\hline \multirow[b]{2}{*}{$\begin{array}{l}\text { Work } \\
\text { history }\end{array}$} & \multicolumn{3}{|c|}{ Men } & \multicolumn{3}{|c|}{ Women } \\
\hline & Africa/Asia & Europe/America & Israel & Africa/Asia & Europe/America & Israel \\
\hline $\begin{array}{l}\text { One spell - } \\
\text { out-spell }\end{array}$ & 100 & 100 & 100 & 100 & 100 & 100 \\
\hline $\begin{array}{l}\text { Two spells - } \\
\text { in-spell } \\
\text { out-spell }\end{array}$ & $\begin{array}{l}73 \\
27\end{array}$ & $\begin{array}{l}74 \\
26\end{array}$ & $\begin{array}{l}73 \\
27\end{array}$ & $\begin{array}{l}55 \\
45\end{array}$ & $\begin{array}{l}64 \\
36\end{array}$ & $\begin{array}{l}62 \\
38\end{array}$ \\
\hline $\begin{array}{c}\text { Three spells } \\
\text { out-spell } \\
\text { in-spell } \\
\text { out-spell } \\
\end{array}$ & $\begin{array}{l}30 \\
31 \\
39 \\
\end{array}$ & $\begin{array}{l}29 \\
38 \\
33 \\
\end{array}$ & $\begin{array}{l}32 \\
33 \\
35 \\
\end{array}$ & $\begin{array}{l}44 \\
14 \\
42 \\
\end{array}$ & $\begin{array}{l}40 \\
19 \\
41 \\
\end{array}$ & $\begin{array}{l}38 \\
19 \\
43 \\
\end{array}$ \\
\hline $\begin{array}{c}\text { Four spells - } \\
\text { in-spell } \\
\text { out-spell } \\
\text { in-spell } \\
\text { out-spell } \\
\end{array}$ & $\begin{array}{c}25 \\
9 \\
42 \\
24 \\
\end{array}$ & $\begin{array}{c}34 \\
9 \\
36 \\
21 \\
\end{array}$ & $\begin{array}{c}41 \\
8 \\
28 \\
22 \\
\end{array}$ & $\begin{array}{l}25 \\
12 \\
32 \\
31 \\
\end{array}$ & $\begin{array}{l}32 \\
11 \\
30 \\
27 \\
\end{array}$ & $\begin{array}{l}34 \\
12 \\
24 \\
29 \\
\end{array}$ \\
\hline $\begin{array}{c}\text { Five spells - } \\
\quad \text { out-spell } \\
\text { in-spell } \\
\text { out-spell } \\
\text { in-spell } \\
\text { out-spell }\end{array}$ & $\begin{array}{l}20 \\
14 \\
12 \\
24 \\
29\end{array}$ & $\begin{array}{l}19 \\
18 \\
11 \\
26 \\
25\end{array}$ & $\begin{array}{l}24 \\
14 \\
10 \\
25 \\
26\end{array}$ & $\begin{array}{c}31 \\
9 \\
16 \\
12 \\
32\end{array}$ & $\begin{array}{l}28 \\
12 \\
14 \\
15 \\
31\end{array}$ & $\begin{array}{c}28 \\
9 \\
17 \\
18 \\
28\end{array}$ \\
\hline $\begin{array}{l}\text { Six spells or } \\
\text { more }\end{array}$ & $\begin{array}{c}\text { Sum in-spells } \\
=56 \\
\text { Sum out-spells } \\
=44\end{array}$ & $\begin{array}{l}\text { Sum in-spells } \\
=60 \\
\text { Sum out-spells } \\
=40\end{array}$ & $\begin{array}{c}\text { Sum in-spells }= \\
56 \\
\text { Sum out-spells } \\
=44\end{array}$ & $\begin{array}{c}\text { Sum in-spells } \\
=60 \\
\text { Sum out-spells } \\
=40\end{array}$ & $\begin{array}{c}\text { Sum in-spells } \\
=46 \\
\text { Sum out-spells } \\
=54\end{array}$ & $\begin{array}{c}\text { Sum in-spells } \\
=45 \\
\text { Sum out-spells } \\
=55\end{array}$ \\
\hline
\end{tabular}




\section{Appendix Table 5}

Share of time spent in work or non-work by individuals currently not in work, by gender and marital status

\begin{tabular}{|l|c|c|c|c|c|c|}
\hline \multirow{2}{*}{$\begin{array}{c}\text { Marital } \\
\text { status }\end{array}$} & $\begin{array}{c}\text { Number } \\
\text { in } \\
\text { sample }\end{array}$ & $\begin{array}{c}\text { Share of } \\
\text { time in } \\
\text { work } \\
(\%)\end{array}$ & $\begin{array}{c}\text { Share of } \\
\text { time not } \\
\text { in work } \\
(\%)\end{array}$ & $\begin{array}{c}\text { Number } \\
\text { in } \\
\text { sample }\end{array}$ & $\begin{array}{c}\text { Share of } \\
\text { time in } \\
\text { work } \\
(\%)\end{array}$ & $\begin{array}{c}\text { Share of } \\
\text { time not } \\
\text { in work } \\
(\%)\end{array}$ \\
\hline Married & 26,674 & 54.4 & 45.6 & 34,018 & 28.0 & 72.0 \\
\hline $\begin{array}{l}\text { Divorced \& } \\
\text { Widowed }\end{array}$ & 2,190 & 27.6 & 72.4 & 5,164 & 29.6 & 70.4 \\
\hline Single & 2,656 & 41.3 & 58.7 & 1,961 & 28.4 & 71.6 \\
\hline Total & 31,520 & 51.2 & 48.8 & 41,143 & 28.1 & 71.9 \\
\hline
\end{tabular}

\section{Appendix Table 6}

Frequency distribution of spells experienced for individuals currently not in work, by gender and marital status

(\%)

\begin{tabular}{|l|c|c|c|c|c|c|}
\hline $\begin{array}{l}\text { Number of spells } \\
\text { (in-spells and } \\
\text { out-spells) }\end{array}$ & \multicolumn{3}{|c|}{ Men } & \multicolumn{3}{|c|}{ Women } \\
\cline { 2 - 6 } & Married & $\begin{array}{l}\text { Divorced \& } \\
\text { widowed }\end{array}$ & Single & Married & $\begin{array}{l}\text { Divorced \& } \\
\text { widowed }\end{array}$ & Single \\
\hline One spell & 16.3 & 21.4 & 34.1 & 30.1 & 28.4 & 39.2 \\
\hline Two spells & 26.2 & 14.6 & 8.4 & 7.0 & 6.0 & 6.7 \\
\hline Three spells & 3.7 & 4.0 & 7.2 & 9.8 & 9.3 & 4.9 \\
\hline Four spells & 19.1 & 12.8 & 6.4 & 8.1 & 6.6 & 6.8 \\
\hline Five spells & 3.3 & 4.7 & 5.4 & 7.5 & 7.6 & 3.9 \\
\hline Six spells or more & 31.4 & 42.6 & 38.5 & 37.5 & 42.2 & 38.4 \\
\hline Total & 100.0 & 100.0 & 100.0 & 100.0 & 100.0 & 100.0 \\
\hline
\end{tabular}


Appendix Table 7

Relative spell durations of those currently not in work, by gender and marital status

(\%)

\begin{tabular}{|c|c|c|c|c|c|c|}
\hline \multirow[b]{2}{*}{ Work history } & \multicolumn{3}{|c|}{ Men } & \multicolumn{3}{|c|}{ Women } \\
\hline & Married & $\begin{array}{c}\text { Widowed \& } \\
\text { divorced }\end{array}$ & Single & Married & $\begin{array}{c}\text { Widowed \& } \\
\text { divorced }\end{array}$ & Single \\
\hline $\begin{array}{l}\text { One spell - } \\
\text { out-spell }\end{array}$ & 100 & 100 & 100 & 100 & 100 & 100 \\
\hline $\begin{array}{l}\text { Two spells - } \\
\text { in-spell } \\
\text { out-spell }\end{array}$ & $\begin{array}{l}74 \\
26\end{array}$ & $\begin{array}{l}70 \\
30\end{array}$ & $\begin{array}{l}59 \\
41\end{array}$ & $\begin{array}{l}61 \\
39\end{array}$ & $\begin{array}{l}59 \\
41\end{array}$ & $\begin{array}{l}62 \\
38\end{array}$ \\
\hline $\begin{array}{c}\text { Three spells - } \\
\text { out-spell } \\
\text { in-spell } \\
\text { out-spell }\end{array}$ & $\begin{array}{l}28 \\
38 \\
33\end{array}$ & $\begin{array}{l}38 \\
14 \\
48\end{array}$ & $\begin{array}{l}36 \\
17 \\
47\end{array}$ & $\begin{array}{l}42 \\
16 \\
42\end{array}$ & $\begin{array}{l}43 \\
26 \\
41\end{array}$ & $\begin{array}{l}35 \\
23 \\
42\end{array}$ \\
\hline $\begin{array}{l}\text { Four spells - } \\
\text { in-spell } \\
\text { out-spell } \\
\text { in-spell } \\
\text { out-spell }\end{array}$ & $\begin{array}{c}29 \\
8 \\
40 \\
22\end{array}$ & $\begin{array}{l}31 \\
11 \\
33 \\
25\end{array}$ & $\begin{array}{l}26 \\
10 \\
29 \\
34\end{array}$ & $\begin{array}{l}28 \\
12 \\
31 \\
30\end{array}$ & $\begin{array}{l}32 \\
11 \\
31 \\
26\end{array}$ & $\begin{array}{l}34 \\
10 \\
30 \\
26\end{array}$ \\
\hline $\begin{array}{l}\text { Five spells - } \\
\text { out-spell } \\
\text { in-spell } \\
\text { out-spell } \\
\text { in-spell } \\
\text { out-spell }\end{array}$ & $\begin{array}{l}19 \\
17 \\
11 \\
28 \\
25\end{array}$ & $\begin{array}{l}21 \\
11 \\
15 \\
17 \\
35\end{array}$ & $\begin{array}{l}24 \\
10 \\
12 \\
15 \\
38\end{array}$ & $\begin{array}{l}30 \\
10 \\
15 \\
14 \\
31\end{array}$ & $\begin{array}{l}29 \\
10 \\
16 \\
12 \\
32\end{array}$ & $\begin{array}{l}25 \\
10 \\
18 \\
12 \\
34\end{array}$ \\
\hline $\begin{array}{l}\text { Six spells or } \\
\text { more }\end{array}$ & $\begin{array}{c}\text { Sum in-spells } \\
=60 \\
\text { Sum out-spells } \\
=40\end{array}$ & $\begin{array}{c}\text { Sum in-spells } \\
=50 \\
\text { Sum out-spells } \\
=50\end{array}$ & $\begin{array}{c}\text { Sum in-spells } \\
=43 \\
\text { Sum out-spells } \\
=57\end{array}$ & $\begin{array}{l}\text { Sum in-spells } \\
\quad=42 \\
\text { Sum out-spells } \\
=58\end{array}$ & $\begin{array}{c}\text { Sum in-spells } \\
=41 \\
\text { Sum out-spells } \\
=59\end{array}$ & $\begin{array}{c}\text { Sum in-spells } \\
\quad=50 \\
\text { Sum out-spells } \\
=50\end{array}$ \\
\hline
\end{tabular}

Appendix Table 8

Share of time spent in work or non-work by individuals currently not in work, by gender and age group

\begin{tabular}{|c|c|c|c|c|}
\hline \multirow{2}{*}{$\begin{array}{c}\text { Age } \\
\text { group }\end{array}$} & $\begin{array}{c}\text { Share of time } \\
\text { in work } \\
(\%)\end{array}$ & $\begin{array}{c}\text { Share of time } \\
\text { not in work } \\
(\%)\end{array}$ & $\begin{array}{c}\text { Share of time } \\
\text { in work } \\
(\%)\end{array}$ & $\begin{array}{c}\text { Share of time } \\
\text { not in work } \\
(\%)\end{array}$ \\
\hline $\mathbf{3 5 - 4 0}$ & 46.2 & 53.8 & 30.8 & 69.2 \\
\hline $\mathbf{4 1 - 4 5}$ & 52.0 & 48.0 & 27.6 & 72.4 \\
\hline $\mathbf{4 6 - 5 0}$ & 53.6 & 46.4 & 28.1 & 71.9 \\
\hline $\mathbf{5 1 - 5 5}$ & 54.3 & 45.7 & 26.8 & 73.2 \\
\hline $\mathbf{5 6 - 6 0}$ & 53.2 & 46.7 & 26.2 & 73.8 \\
\hline Total & 51.2 & 48.8 & 28.1 & 71.9 \\
\hline
\end{tabular}




\section{Appendix Table 9}

Frequency distribution of spells experienced for individuals currently not in work, by gender and age group

\begin{tabular}{|c|c|c|c|}
\hline \multirow{2}{*}{$\begin{array}{l}\text { Number of spells } \\
\text { (in-spells and } \\
\text { out-spells) }\end{array}$} & \multicolumn{3}{|c|}{$\begin{array}{c}\text { Frequency distribution of sample in each } \\
\text { spell category }(\%)\end{array}$} \\
\hline & $\begin{array}{c}\text { Age } \\
\text { group }\end{array}$ & Men & Women \\
\hline \multirow{5}{*}{ One spell } & $35-40$ & 2.1 & 21.2 \\
\hline & $41-45$ & 17.2 & 27.6 \\
\hline & $46-50$ & 17.0 & 31.2 \\
\hline & $51-55$ & 16.7 & 36.5 \\
\hline & $56-60$ & 17.2 & 40.1 \\
\hline \multirow{5}{*}{ Two spells } & $35-40$ & 14.4 & 4.2 \\
\hline & $41-45$ & 24.6 & 5.3 \\
\hline & $46-50$ & 27.8 & 7.5 \\
\hline & $51-55$ & 29.0 & 8.9 \\
\hline & $56-60$ & 30.6 & 10.0 \\
\hline \multirow{5}{*}{ Three spells } & $35-40$ & 5.5 & 7.7 \\
\hline & $41-45$ & 4.4 & 10.1 \\
\hline & $46-50$ & 3.1 & 11.2 \\
\hline & $51-55$ & 3.0 & 10.1 \\
\hline & $56-60$ & 3.0 & 9.0 \\
\hline \multirow[t]{5}{*}{ Four spells } & $35-40$ & 11.2 & 6.1 \\
\hline & $41-45$ & 16.8 & 7.4 \\
\hline & $46-50$ & 21.4 & 8.1 \\
\hline & $51-55$ & 21.7 & 8.5 \\
\hline & $56-60$ & 22.5 & 9.9 \\
\hline \multirow[t]{5}{*}{ Five spells } & $35-40$ & 4.9 & 7.6 \\
\hline & $41-45$ & 3.6 & 8.5 \\
\hline & $46-50$ & 2.9 & 7.4 \\
\hline & $51-55$ & 2.7 & 6.5 \\
\hline & $56-60$ & 2.3 & 6.1 \\
\hline \multirow{5}{*}{ Six spells or more } & $35-40$ & 43.0 & 53.3 \\
\hline & $41-45$ & 33.3 & 41.0 \\
\hline & $46-50$ & 27.8 & 34.6 \\
\hline & $51-55$ & 26.8 & 29.5 \\
\hline & $56-60$ & 24.4 & 24.9 \\
\hline \multirow[t]{5}{*}{ Total } & $35-40$ & 100.0 & 100.0 \\
\hline & $41-45$ & 100.0 & 100.0 \\
\hline & $46-50$ & 100.0 & 100.0 \\
\hline & $51-55$ & 100.0 & 100.0 \\
\hline & $56-60$ & 100,0 & 100,0 \\
\hline
\end{tabular}




\section{Appendix Table 10}

Share of time spent in work or non-work by individuals currently employed, by gender and years of schooling

\begin{tabular}{|c|c|c|c|c|c|c|}
\hline \multirow[b]{2}{*}{$\begin{array}{l}\text { Years of } \\
\text { schooling }\end{array}$} & \multicolumn{3}{|c|}{ Men } & \multicolumn{3}{|c|}{ Women } \\
\hline & $\begin{array}{l}\text { Number } \\
\text { in } \\
\text { sample }\end{array}$ & $\begin{array}{c}\text { Share of } \\
\text { time in } \\
\text { work } \\
(\%)\end{array}$ & $\begin{array}{c}\text { Share of } \\
\text { time not } \\
\text { in work } \\
(\%)\end{array}$ & $\begin{array}{l}\text { Number } \\
\text { in } \\
\text { sample }\end{array}$ & $\begin{array}{l}\text { Share of } \\
\text { time in } \\
\text { work } \\
(\%)\end{array}$ & $\begin{array}{c}\text { Share of } \\
\text { time not } \\
\text { in work } \\
(\%)\end{array}$ \\
\hline $0-8$ years & & 86.3 & 13.7 & & 69.2 & 30.8 \\
\hline 9-12 years & & 89.2 & 10.8 & & 75.6 & 24.4 \\
\hline 13+ years & & 90.4 & 9.6 & & 83.8 & 16.2 \\
\hline Total & 72,720 & 89.3 & 10.7 & 69,750 & 78.3 & 21.7 \\
\hline
\end{tabular}

\section{Appendix Table 11}

Share of time spent in work or non-work by individuals currently not in work, by gender and years of schooling

\begin{tabular}{|c|c|c|c|c|c|c|}
\hline \multirow[b]{2}{*}{$\begin{array}{c}\text { Years of } \\
\text { schooling }\end{array}$} & \multicolumn{3}{|c|}{ Men } & \multicolumn{3}{|c|}{ Women } \\
\hline & $\begin{array}{l}\text { Number } \\
\text { in } \\
\text { sample }\end{array}$ & $\begin{array}{c}\text { Share of } \\
\text { time in } \\
\text { work } \\
(\%)\end{array}$ & $\begin{array}{c}\text { Share of } \\
\text { time not } \\
\text { in work } \\
(\%)\end{array}$ & $\begin{array}{c}\text { Number } \\
\text { in } \\
\text { sample }\end{array}$ & $\begin{array}{c}\text { Share of } \\
\text { time in } \\
\text { work } \\
(\%)\end{array}$ & $\begin{array}{c}\text { Share of } \\
\text { time not } \\
\text { in work } \\
(\%)\end{array}$ \\
\hline $0-8$ years & & 45.6 & 54.4 & & 20.2 & 79.8 \\
\hline 9-12 years & & 52.4 & 47.6 & & 27.5 & 72.5 \\
\hline $13+$ years & & 53.4 & 46.6 & & 36.6 & 63.4 \\
\hline Total & 31,520 & 51.2 & 48.8 & 41,143 & 28.1 & 71.9 \\
\hline
\end{tabular}

\section{Appendix Table 12}

Frequency distribution of spells experienced for individuals currently in work, by gender and years of schooling

(\%)

\begin{tabular}{|l|c|c|c|c|c|c|}
\hline \multirow{2}{*}{$\begin{array}{l}\text { Number of } \\
\text { spells } \\
\text { (in-spells } \\
\begin{array}{l}\text { and out- } \\
\text { spells) }\end{array}\end{array}$} & \multicolumn{3}{|c|}{ Mears of schooling } & \multicolumn{3}{c|}{ Women } \\
\cline { 2 - 7 } & $\mathbf{0 - 8}$ years & $\mathbf{9 - 1 2}$ years & $\mathbf{1 3 +}$ years & $\mathbf{0 - 8}$ years & $\mathbf{9 - 1 2}$ years & $\mathbf{1 3 +}$ years \\
\hline One spell & 24.9 & 33.4 & 37.6 & 11.8 & 18.8 & 21.1 \\
\hline Two spells & 3.2 & 3.2 & 4.1 & 7.1 & 6.3 & 4.6 \\
\hline Three spells & 25.8 & 25.3 & 24.4 & 13.9 & 15.5 & 20.3 \\
\hline Four spells & 3.4 & 3.2 & 3.8 & 10.2 & 7.7 & 5.7 \\
\hline Five spells & 11.5 & 10.4 & 9.9 & 7.2 & 9.2 & 13.1 \\
\hline $\begin{array}{l}\text { Six spells or } \\
\text { more }\end{array}$ & 31.2 & 24.5 & 20.2 & 49.9 & 42.5 & 35.2 \\
\hline Total & 100.0 & 100.0 & 100.0 & 100.0 & 100.0 & 100.0 \\
\hline
\end{tabular}


Appendix Table 13

Frequency distribution of spells experienced for individuals currently not in work, by gender and years of schooling

(\%)

\begin{tabular}{|l|c|c|c|c|c|c|}
\hline \multirow{2}{*}{$\begin{array}{l}\text { Number of } \\
\text { spells } \\
\text { (in-spells } \\
\begin{array}{l}\text { and out- } \\
\text { spells) }\end{array}\end{array}$} & \multicolumn{3}{|c|}{ Men } & \multicolumn{3}{c|}{ Women } \\
\cline { 2 - 7 } & $\mathbf{0 - 8}$ years & $\mathbf{9 - 1 2}$ years & $\mathbf{1 3 +}$ years & $\mathbf{0 - 8}$ years & $\mathbf{9 - 1 2}$ years & $\mathbf{1 3}+$ years \\
\hline One spell & 19.9 & 16.9 & 19.3 & 40.0 & 27.8 & 26.1 \\
\hline Two spells & 19.9 & 24.3 & 26.2 & 4.8 & 6.5 & 9.2 \\
\hline Three spells & 4.6 & 3.9 & 3.9 & 10.9 & 10.2 & 6.9 \\
\hline Four spells & 17.4 & 18.0 & 17.0 & 5.8 & 7.4 & 10.4 \\
\hline Five spells & 3.6 & 3.3 & 3.9 & 7.8 & 7.9 & 5.9 \\
\hline $\begin{array}{l}\text { Six spells or } \\
\text { more }\end{array}$ & 34.6 & 33.6 & 29.7 & 30.8 & 40.1 & 41.4 \\
\hline Total & 100.0 & 100.0 & 100.0 & 100.0 & 100.0 & 100.0 \\
\hline
\end{tabular}




\section{Endnotes}

1 While very little longitudinal labor force data are available in Israel, some limited progress has been made in recent years in this regard. Panel data relating to three waves of Russian immigration for the years 1990-1993 provide some information on the labor market experience of new immigrants but they constitute a very small section of the labor force. Research by Stier (1998), based on individual labor force information from subsequent panels in the Labor Force Survey, analyses short-term transitions of women between alternative employment statuses; however, the data allow the generation of longitudinal data for a period of only about a year. An ongoing labor market survey to provide panel data is now being planned by the Central Bureau of Statistics, but it will take many years before longitudinal data are generated.

${ }^{2}$ Labor force participation rates for 1995 were 62.6 percent for men and 45.4 percent for women; unemployment rates for men and women, respectively, were 5.1 percent and 7.9 percent (Central Bureau of Statistics, 1996).

${ }^{3}$ Results for the non-employed sample by marital status, age group and education are provided in Appendix Tables 5-9, 11 and 13.

${ }^{4}$ Summary results only are presented for the country of origin (i.e. ethnic group) analysis. Tabulations with the full range of results of work histories differentiated by ethnic origin appear in Appendix Tables 1-4.

5 The percentage of Western workers grew dramatically after 1989, when almost a million immigrants from the former USSR arrived in Israel. This is not reflected in our sample, which excludes new immigrants who arrived in Israel after 1980.

${ }^{6}$ See Neuman (2004) for a comprehensive analysis of immigrant waves during the period 1882-1998.

7 These cultural differences between the two ethnic groups reflect differing prevailing cultural norms concerning gender roles in relation to employment, childcare and household duties, between European/American and Asian/African countries. For example, the share of women in the labor force (in 1995) in such Western countries as Sweden (48 percent) and the US (47 percent) greatly exceeds that in India (12 percent) and in Saudi Arabia, a mere 8 percent. (Data from International Labour Office, Bulletin of Labour Statistics).

${ }^{8}$ Marital status is recorded for December 1995. Workers who were single in 1995 maintained this same status since 1983. However, those who were in the married or divorced/widowed category in 1995 might have experienced a change in marital status during the period 1983-1995.

9 Our results are also consistent with the predictions of other theories in the economics of marriage, such as bargaining models (Manser and Brown, 1980), market models of marriage (Becker, 1973 and Grossbard-Schectman, 1984) and the separate spheres bargaining model of Lundburg and Pollak (1993).

10 Tables with relative spell durations, by gender age group, are available from the authors on request.

11 Falling from over 80 percent in the beginning of the 1980 s to about 50 percent in 1995 (Cohen et al, 2001). 